\title{
Clinical signs associated with a case of iatrogenic poisoning by a turpentine-based commercial product in a 3-day-old foal
}

\section{Sinais clínicos associados a um caso de envenenamento iatrogênico de um equino com três dias de idade por um produto comercial baseado em terebintina}

\author{
Abelardo Morales Briceño ${ }^{1}$ (D); Hilal Al Mahrouqi ${ }^{1}$; Abdallah Al Kayyoomi ${ }^{1}$; Harmon Oliva ${ }^{1}$; \\ Kimberly Brewer ${ }^{2}$; Thomas Tobin ${ }^{3}$ \\ ${ }^{1}$ SHS Veterinary Center, Al Wathba, Abu Dhabi, United Arab Emirates \\ ${ }^{2} 1711$ Lakefield North Court, Wellington - FL, United States \\ ${ }^{3}$ University of Kentucky, College of Agriculture, Food and Environment, Maxwell H. Gluck Equine Research Center, \\ Lexington - KY, United States
}

\begin{abstract}
The aim of this study is to report a case of iatrogenic poisoning by a turpentine-based commercial product in a 3-day-old foal and the successful treatment of this condition. A 3-day-old male foal presented with acute cardio-respiratory collapse, anaphylactic shock, severe respiratory distress, dyspnea and pulmonary edema. The animal's history included previous administration of a commercial veterinary product (UNITIPAN). Clinical examination revealed: temperature: $\left(39.9^{\circ} \mathrm{C}\right)$, pulse: $135 \mathrm{bpm}$, respiration: $51 \mathrm{bpm}$, mucous membranes: moist and congested, capillary refill time: $3 \mathrm{sec}$ or less. The foal was treated with emergency hydration, duphalyte, steroidal anti-inflammatory, atropine sulphate and antibiotic. After $6 \mathrm{~h}$ of treatment, the foal was stabilized and vital signs were normalized $8 \mathrm{~h}$ after treatment start.
\end{abstract}

Keywords: Anaphylaxis. Emergency. Equine. Intoxication. Pinaceae.

\section{RESUMO}

O objetivo deste estudo é relatar um caso de intoxicação iatrogênica por um produto comercial a base de terebentina em um potro de três días de idade e o sucesso do tratamento dessa condição. Um potro de três dias de idade foi apresentou um colapso cardiorrespiratório agudo, choque anafilático, desconforto respiratório grave, dispnéia e edema pulmonar. A história incluiu a administração prévia de um produto veterinário comercial (UNITIPAN). Ao exame clínico: temperatura: $\left(39,9^{\circ} \mathrm{C}\right)$, pulso: $135 \mathrm{bpm}$, respiração $51 \mathrm{bpm}$, membranas mucosas, congestionamento úmido, tempo de enchimento capilar: três segundos ou menos. O potro foi tratado com hidratação de emergência, duphalyte, anti-inflamatório esteroidal, sulfato de atropina e antibiótico. Após seis horas de tratamento, o potro foi estabilizado e os sinais vitais foram normalizados depois de oito horas do inicio do tratamento. O presente trabalho relata um caso de intoxicação iatrogênica por um produto à base de terebintina comercial em um potro de três dias de idade com rápido desenvolvimento de sinais de toxicidade aguda e uma resposta muito favorável ao tratamento sintomático.

Palavras-chave: Anafilaxia. Emergência. Equino. Intoxicação. Pinaceae.

Correspondence to:

Abelardo Morales Briceno

SHS Veterinary Center

Al Wahtbah, Stable 56, Abu Dhabi, United Arab Emirates

e-mail: aamorales13@gmail.com

Received: January 6, 2019

Approved: August 25, 2019
How to cite: Briceño AM, Al Mahrouqi H, Al Kayyoomi A, Oliva H; Brewer K; Tobin T. Clinical signs associated with a case of iatrogenic poisoning by a turpentine-based commercial product in a 3-day-old foal. Braz J Vet Res Anim Sci. 2019;56(4): e153366. https://doi.org/10.11606/ issn.1678-4456.bjvras.2019.153366 


\section{Introduction}

The aim of this study is to report a case of iatrogenic poisoning by a turpentine-based commercial product in a 3-day-old foal and the successful treatment of this condition. In recent years, natural medicine, also called holistic medicine, has had a great upsurge in veterinary medicine. Many homeopathic treatments are used worldwide, including many already marketed and distributed for veterinary use. Some scientific studies have shown efficacy of these drugs in some pathologies in other animals (Lees et al., 2017). They are still under study, but even this type of therapy is carried out continuously in veterinary medicine. Complementary and alternative therapies have a definite place in veterinary medicine today. With the public now demanding access to a full range of conventional and complementary therapies, the best scenario is to have all therapies available, for there appears to be a place and a need for all of them in the right situation (Vockeroth, 1999). Turpentine is an oleo resin obtained from various species of pine (Güzel \& Açikgöz, 2015). It is a liquid mixture of substances extracted from various trees in the pine family (Pinaceae). Depending on the starting material, several types of turpentine are possible (for example, gum spirit of turpentine), although chemically, they all consist primarily of alpha-pinene (80-56-8), beta-pinene (127-91-3), and other terpenes (Troulakis et al., 1997). Turpentine oil poisoning occurs after swallowing turpentine oil or breathing in the fumes. In humans, some reports of toxicity are described: First, turpentine vapor is irritating to the eyes, nose, and throat. When inhaled, turpentine causes nausea, vomiting, headache, difficult breathing and eventual loss of consciousness. Topically applied, liquid turpentine irritates skin. If ingested, turpentine can irritate the entire digestive system, and may injure the kidneys. If liquid turpentine is taken into lungs, it can cause severe pneumonitis. Turpentine is a skin irritant and skin contact may cause eczema. Workers in the chemical, rubber and welding industries exposed to turpentine have developed contact dermatosis (Troulakis et al., 1997). Turpentine was formerly used as an ingredient in many ointments, liniments, and lotions for treating minor aches and pains as well as colds, and has a history of use as a veterinary medication. There are commercial presentations for use in veterinary medicine for the prevention of tympanization in ruminants and camels and for the treatment of colic in horses. This commercial product is commonly used in Middle Eastern countries for impaction, tympanism and colic in small ruminants, camel and adult horses, and is also used in newborn animals (sheep, goats and camels) with meconium retention. This article describes the clinical and toxicological aspects of administration/ingestion of turpentine by a foal, and proposes the applied therapeutics for this case.

\section{Case Report}

A 3-day-old male foal presented with acute cardio-respiratory collapse, anaphylactic shock, severe respiratory distress, dyspnea and pulmonary edema. The history included previous administration of a commercial veterinary product (UNITIPAN), reportedly by the owner. The product was orally administered in a single $10 \mathrm{ml}$ dose, and contained $35 \mathrm{gm}$ turpentine, $1.25 \mathrm{gm}$ anise oil and $125 \mathrm{~mL}$ excipient. On clinical examination, the foal presented (approximately $2 \mathrm{~h}$ after treatment) the following values: temperature: 99.5-102. $1^{\circ} \mathrm{F}\left(39.9^{\circ} \mathrm{C}\right)$, pulse: 135 beats per minute, respiration (breathing rate): 51 breaths per minute, mucous membranes (gums): moist congested, capillary refill time: $3 \mathrm{sec}$ or less. It was not possible to perform hematological, biochemical and toxicological study during the emergency, because the event occurred in a desert stable (Al Wathba) and there was no laboratory for immediate samples processing of the samples immediately. The foal was treated with emergency hydration intravenous (lactated Ringer's solution) 3 liters, duphalyte (vitamin B complex, electrolytes, amino acids and dextrose $500 \mathrm{ml}$, glucose $5 \% 100 \mathrm{ml}$, steroidal anti-inflammatory: dexamethasone (sodium phosphate) $2 \mathrm{mg}$ excipient qs $1 \mathrm{~mL}$, intravenous $2 \mathrm{ml}$, atropine sulphate $0.65 \mathrm{mg} / \mathrm{mL} 0.8 \mathrm{~mL}$ and antibiotic (benzylpenicillin procainum $200000 \mathrm{IE} / \mathrm{mL}$ and dihydrostreptomycin sulfas $200 \mathrm{mg} / \mathrm{mL}$ ) (intramuscular injection), $3 \mathrm{~mL}$, only antibiotic and steroidal anti-inflammatory, was applied for 7 days. After $6 \mathrm{~h}$ of treatment, the foal was stabilized and vital signs were normalized by $8 \mathrm{~h}$ post initiation of treatment. Respiratory rales were maintained for $72 \mathrm{~h}$, the maneuver of decline (while holding the horse by its hind legs and its head towards the ground, due to gravity, the fluids drain through its nostrils), was performed every $4 \mathrm{~h}$ so that the foal would expel the fluids and part of the tracheal and pulmonary edema through the nasal route.

\section{Discussion}

Poisoning in horses is not a common occurrence, but when it does occur, effects can be disastrous and far-reaching (Equine Disease Quarterly, 2008). Listing all toxic substances is impossible, as virtually everything on the planet can be toxic at sufficiently high dosages (Equine Disease Quarterly, 2008). Turpentine oil causes toxicity when absorbed by the lungs through inhalation or when it enters the gastrointestinal system through oral ingestion 
(Güzel \& Açikgöz, 2015). In humans, clinical effects commence about 2-3 h after it enters the body. The most common effects of turpentine ingestion include a burning sensation in the mouth, pain in the lips, tongue, throat and esophagus, thirst, coughing, vomiting and diarrhea (Güzel \& Açikgöz, 2015). The clinical signs presented by this foal were similar to those described in humans, namely severe symptoms of toxicity that may result in death, including aspiration pneumonitis, acute lung damage, pulmonary edema, resistant metabolic acidosis, serious hypotension, liver failure, renal failure, convulsions, arrhythmia and coma (Güzel \& Açikgöz, 2015). Some reports indicate poisoning by occasional ingestion of the Pinaceae family in cattle (DiTomaso, 2019). Plants which produce toxic amounts of pric acid (i.e. turpentine) weed horses the diet for 60 days to cause, chronic, swelling of jaw and poisoning (Carpenter, 1994). There are few reports of turpentine toxicity in horses and toxicity in foals has not been previously described in the literature. One of the limitations in this study is a toxicological analysis for the detection of turpentine levels in urine and blood, so this report focused on the clinical and therapeutic response, as well as education for the prevention of turpentine poisoning. Plants, feeds, and feed additives: Pastures can contain toxic plants and grasses that can pose risks at certain times of the year or under certain circumstances (Equine Disease Quarterly, 2008). Too many toxic plants exist to list here, and their importance varies greatly with geographic location; however, all weeds should be viewed with suspicion and identified if possible, since many shrubs, trees, and ornamental plants can be toxic to horses (Equine Disease Quarterly, 2008). Outcomes

\section{References}

Carpenter Z. Reducing livestock losses to toxic plants. Texas: Texas Agricultural Extension Service. The Texas A\&M University System. College Station; 1994.

DiTomaso JM. List of plants reported to be poisonous to animals in the United States [Internet]. Davis: University of California, Weed Research and Information Center; 2019 [cited 2013 June 10]. 5 p. Available from: https://wric. ucdavis.edu/PDFs/plants\%20reported\%20to\%20be\%20 poisonous\%20to\%20animals.pdf

Equine Disease Quarterly. Poisoning in Horses: Common Toxic Substances. The Horse [Internet]. 2008 Oct 1 [2019 Fev 01]. Available from: https://thehorse.com/123365/ poisoning-in-horses-common-toxic-substances/ of this event include recognition of the importance of veterinary supervision of all medical treatments, since the unregulated commercialization of veterinary medicines can generate these types of complications, which could be fatal if administered to a foal. Some of the limitations of this study include not having a hematological, biochemical and toxicological study, because the event occurred in a desert stable (Al Wathba) where they do not have a laboratory for immediate samples processing, and the animal was treated during a field emergency. Established emergency treatment considers stopping consumption of the potentially toxic substance, although it is possible to use another therapeutic plan for this type of acute iatrogenic poisoning. However, prevention is the most valuable tool.

\section{Conclusion}

A case was reported of iatrogenic poisoning by a turpentine-based commercial product on a 3-day-old foal with ensuing rapid development of signs of acute toxicity and a very favorable response to symptomatic treatment.

\section{Conflict of interest}

The authors state they have no conflicts of interest to declare.

\section{Ethics Statement}

The ethi-cs and animal welfare statutes were fulfilled.

\section{Acknowledgements}

This article has been funded by SHS Stables \& SHS Veterinary Center, Al Wathba, Abu Dhabi, United Arab Emirates.

Güzel A, Açikgöz M. A lethal danger in the home: turpentine poisoning. Turk J Pediatr. 2015;57(2):177-9.

Lees P, Chambers D, Pelligand L, Toutain PL, Whiting $\mathrm{M}$, Whitehead ML. Comparison of veterinary drugs and veterinary homeopathy: part 2. Vet Rec. 2017;181(8):198-207.

Troulakis G, Tsatsakis AM, Tzatzarakis M, Astrakianakis A, Dolapsakis G, Kostas R. Acute intoxication and recovery following massive turpentine ingestion: clinical and toxicological data. Vet Hum Toxicol. 1997;39(3):155-7.

Vockeroth WG. Veterinary homeopathy: an overview. Can Vet J. 1999;40(8):592-94. 
Financial Support: Funding was provided by SHS Stables \& SHS Veterinary Center, Al Wathba, Abu Dhabi, United Arab Emirates.

Authors Contributions: Abelardo Morales Briceño veterinary pathologist of the case and editor, Hilal Al Mahrouqi participated in the planning of the manuscript,
Abdallah Al Kayyoomi participated in the planning of the manuscript, Harmon Oliva veterinary assistant of the case, Kimberly Brewer participated in the planning, execution and confection of the manuscript, Thomas Tobin participated in the planning, execution and confection of the manuscript. 